Anna Agata Kantarek (akanta@poczta.onet.pl)

Wydział Architektury, Politechnika Krakowska

Iwona Niemiec (iwonapedzich@gmail.com)

INSPACE DESIGN Sp. z o.o.

\title{
Nowy Sącz.
}

Rekreacyjne przedpole miasta u zbiegu rzek

Nowy Sącz.

Recreational city foreground at the confluence

\section{Streszczenie}

Artykuł przedstawia projekt dyplomowy strefy rekreacyjnej Nowego Sącza obejmującej tereny położone u zbiegu rzek Dunajca i Kamienicy Nawojowskiej wraz z propozycją przekształcenia terenów fabryki lodów Koral w krajobrazowo ukształtowany pawilon widokowy Centrum Promocji Regionu. Projekt wykonany został przez Iwonę Niemiec jako dyplom magisterski na Wydziale Architektury Politechniki Krakowskiej, na kierunku Architektura, pod kierunkiem Anny Agaty Kantarek i obroniony w roku 2015.

Słowa kluczowe: miasto przestrzenne, topografia, Nowy Sącz, krajobraz miasta

\section{Abstract}

The paper presents a diploma project of the recreational area of Nowy Sącz, situated at the confluence of the Dunajec and Nawojowska Kamienica rivers with the proposal of transforming the ground of the Koral Ice Cream Factory into a landscape-shaped pavilion of the Regional Promotion Center. The project was made by Iwona Niemiec as a master's degree at the Faculty of Architecture of the Cracow University of Technology, under the direction of Anna Agata Kantarek and defended in the year 2015.

Keywords: Spatial City, topography, Nowy Sącz, Cityscape 


\section{WPROWADZENIE}

Kazimierz Wejchert, pisząc o mieście przestrzennym, wyraził niezwykle trafną intuicję dotyczącą nowych możliwości tworzenia przestrzeni miejskiej:

...odczuwanie i zapamiętywanie przestrzeni będzie się odbywało nadal podobnie jak dziś. Wystąpi być może jedynie przewaga określonych typów sytuacji, w jakich człowiek będzie znajdował się w przestrzeni, mając częściej możność patrzenia na krajobraz miejski z góry lub z dołu, ponad sobą mając różnorodne poziomy, pomosty - „miasto przestrzenne"1.

Współczesne możliwości rozwiązań konstrukcyjnych i materiałowych sprzyjają takiemu myśleniu o przestrzeni urbanistycznej i roli architektury w tak pojętej całości.

Dyskusja dotycząca rozwoju miasta w dużej mierze opiera się na zrozumieniu relacji architektury i całości organizmu miejskiego. Przyjmowane są różne postawy - od skrajnej negacji wymiaru urbanistycznego i całościowego po takie zrozumienie struktury miejskiej i wymogów jej rozwoju, która z kolei neguje autonomię architektury.

W tej dyskusji jest i miejsce na fenomen architektury scalonej z terenem, odpowiadającej na potrzeby tworzenia różnorodności w skali urbanistycznej, również takiej, która może zapewnić zwielokrotnienie i zdynamizowanie powiązań w obrębie miejskich struktur.

Pojęcie architektury topograficznej ${ }^{2}$ daje przybliżenie tych sposobów kształtowania architektury i jej związków z terenem, o którym mówimy.

Chodzi o takie ukształtowanie krajobrazu miejskiego, w którym sposoby użytkowania poszczególnych elementów kubatur i przestrzeni otwartych pozwalają na stworzenie swoistego continuum angażującego wiele poziomów funkcjonalnych i ich wzajemne przenikanie się przy jednoczesnym zachowaniu pełnej dostępności i jej standardu.

W takim spojrzeniu relacje kubatury i przestrzeni otwartej są uzupełnione elementami związanymi z topografią, a w szczególności z poziomami podstawowymi terenu i relacjami do powierzchni wodnych.

\begin{tabular}{|c|}
\hline kubatura użytkowa \\
przestrzeń otwarta \\
topografia \\
(różnice poziomów podstawowych, materia gruntu)
\end{tabular}

Takie przypomnienie istotności relacji tych trzech elementów w opisie struktury przestrzennej jest ważne i dotyczy relacji obecnej od zawsze w dziejach urbanistyki i architektury.

Lokalizacje miast i twierdz były ściśle związane z topografią, a osady, zespoły urbanistyczne czy miasta lokowane na wzgórzach (także takie, które zostały wyrzeźbione w skale). 
Systemy fortyfikacyjne dostarczają tysięcy przykładów rozwiązań ciekawych z punktu widzenia nie tylko ich bezpośredniej użyteczności, ale i atrakcyjności przestrzennej.

Również nietypowe rozwiązania, takie jak zabudowa Çatalhöyük czy słynne ogrody Semiramidy, dają pogląd o niezwykłych możliwościach użytkowania form tworzonych w oparciu o szczególne relacje architektury i terenu.

Znamy też wiele obiektów, w których wykorzystanie powierzchni tarasów i dachów pozwoliło na uzyskanie nowych, wyjątkowo atrakcyjnych przestrzeni publicznych (Katedra w Mediolanie).

Przestrzenność i nakładanie się poziomów użytkowych, co skutkuje budową obiektów inżynierskich i architektonicznych, towarzyszy też rozwojowi sieci komunikacyjnych i relacji do cieków i zbiorników wodnych. Ich istotność dostrzegał już Leonardo da Vinci, projektując wielopoziomowe układy funkcjonalne miasta, a współcześnie wiele miast realizuje takie rozwiązania, w których obecne są funkcje tak stacjonarne, jak i związane z przemieszczaniem się.

Podnoszenie się poziomu miast historycznych jest często wynikiem dostosowywania się do poziomu użytkowego przepraw mostowych, co ukazuje ścisły związek relacji topografii i sieci komunikacyjnych. Architektura zwyczajowo obudowuje tak powstałe struktury tworząc niepowtarzalne przykłady. Wystarczy wspomnieć tu o Paryżu czy Amsterdamie, gdzie poziomy rzeki lub kanału tworzą odrębny poziom użytkowy.

W najbardziej ogólnym spojrzeniu Wenecja czy inne sztucznie budowane wyspy są tu kolejnym przykładem szczególnych relacji z podłożem, którym jest nie tylko woda, ale i podłoże, na którym zostały ufundowane.

Widzimy więc, że tworzenie topograficznej złożoności realizowane było na każdym etapie cywilizacyjnego rozwoju, a u jej podstaw leżała świadomość możliwości wykorzystania, jakie daje konkretna lokalizacja i konkretne uwarunkowania kultury budowania.

Rozwiązania rozwijające relacje architektury, przestrzeni otwartej i topografii mają także spory dorobek współczesny. Zacytowanie kilkunastu z nich daje obraz różnorodny co do skali rozwiązań, funkcji i kontekstu.

Oto wybrane przykłady:

- zespół mieszkaniowy w Wiedniu - Hundertwasserhaus (F. Hundertwasser, 1983-1985)

- rozbudowa Neue Staatsgalerie w Stuttgarcie (J. Stirling, 1984)

- termalna wioska hotelowa Bad Blumau (F. Hundertwasser, 1993-1997)

- Museumplein w Amsterdamie - parking, przestrzeń komercyjna (Zaanen Spanjers CS Architects, 1993-1997)

- Biblioteka Francuska w Paryżu (D. Perrault)

- Stuttgart 21, przebudowa sieci kolejowej i rejonu dworca (Trojan, Trojan + Neu, Darmstadt, od 1994)

- Villa Vals (Bjarne Mastenbroek, Christian Müller, SeARCH, CMA, 2009)

- realizacje Renzo Piano: Nemo, Amsterdam, 1997 
Auditorium Parco de la Musica, Rzym, 2002

Paul Klee Zentrum, Berno, 2005

California Academy of Sciences (the Kimball Natural History Museum, San Francisco, 2008)

- sztuczne góry - Jakob Tigges The Berg w Berlinie, 2009, Guallart Architects, Denia Mountain, Alicante, Hiszpania, 2002

- Muzeum Ludzkiego Ciała, Montpellier, BIG, 2014-2018

- rozwiązania krajobrazowe współczesnych parków i promenad:

- Paryż, Parc La Villette, Bernard Tschumi,1982,

- Paryż, Parc André Citroën, 1992,

- Paryż, Parc Bercy, Bernard Huet, Marylène Ferrand, Jean-Pierre Feugas, Bernard Leroy, Ian Le Caisne, Philippe Raguin 1997,

- Paryż, Promenade Plantée, Jacques Vergely, Philippe Mathieux, Patrick Berger, 1993, Jardin d'Atlantic),

- Nowy York The High Line, James Corner Field Operations, Diller Scofidio + Renfro, 2003)

- Kirstenbosch Centenary Tree Canopy Walkway, Mark Thomas Architects, Henry Fagan \& Partners, 2013-2014

- Arche de la Défense, Paryż, 1990

- Biblioteka Uniwersytetu Warszawskiego (Marek Budzyński, Zbigniew Badowski, Krystyna Ilmurzyńska, 1993-2002)

- Plac Solidarności i Centrum Dialogu „Przełomy” (KWK Promes R. Konieczny, 2009)

- Międzynarodowe Centrum Kongresowe (JEMS Architekci, 2015)

\section{NOWY SAZCZ - UWARUNKOWANIA PRZESTRZENNE}

Nowy Sącz, trzecie pod względem powierzchni i liczby mieszkańców miasto w Małopolsce, jest również jednym z najstarszych miast w województwie. Lokowane w XII wieku, dzięki korzystnemu położeniu przy szlaku łączącym Polskę z Węgrami, miasto stało się ważnym ośrodkiem wymiany handlowej.

Dziś jest głównym węzłem komunikacyjnym i turystycznym regionu. Jest też najważniejszym w regionie centrum gospodarki i innowacyjności; rozwija szkolnictwo wyższe.

Miasto liczy ponad 80 tys. mieszkańców, kiedyś było stolicą województwa (1975-1998), obecnie jest miastem powiatowym³ .

Najstarsza część miasta zlokalizowana jest w widłach dwóch rzek - Dunajca i Kamienicy Nawojowskiej. Naturalny rozwój miasta to jego południowe tereny, jak również osiedla położone po przeciwnych brzegach rzek. W ostatnich latach miasto rozwija się także wzdłuż drogi prowadzącej w kierunku północnym. Obszar Starówki i zbieg rzek nadal pozostają dominantą przestrzenną i funkcjonalną miasta. 
Lokalizacja na trasach prowadzących do rekreacyjnych miejscowości górskich, takich jak Krynica, Piwniczna, Krościenko czy Rożnów, to dodatkowe wzmocnienie atrakcyjności miasta i jego starego centrum, a umiejscowienie w kotlinie i widoki na pobliskie pasma Beskidów, a także Pienin i Tatr dopełniają wartości kompozycyjnych zespołu.

Projektowany teren zlokalizowany jest w bezpośrednim sąsiedztwie Starego Miasta pomiędzy rzekami Dunajec i Kamienica Nawojowska a dawnym murem obronnym. Stanowi miejsce bardzo istotne nie tylko ze względów kompozycyjnych, ale i orientujące w strukturze całego miasta. To węzeł wjazdowy od północy (kierunek skupiający dojazd m.in. z Warszawy, Krakowa, Wrocławia, Katowic, Łodzi i Poznania). Wyjątkowo atrakcyjnie zlokalizowaną przestrzeń (także ze względu na miejsce zbiegu rzek) przecinają dwie bardzo ruchliwe ulice, przez co tereny te pozostają niewykorzystane i stanowią jedynie bufor i nieużywane sąsiedztwo ruchu kołowego.

Atrakcyjny widok, jaki mogłaby dla odwiedzających stanowić panorama Starego Miasta i ruiny Zamku Jagiellonów, zakłóca chaos przestrzeni, podporządkowanie terenu ruchowi kołowemu oraz fatalne sąsiedztwo przypadkowych i niszczejących budynków oraz nieodpowiednio dobranych funkcji (fabryka lodów, parking dla samochodów ciężarowych).

Teren u zbiegu rzek przejęty kiedyś przez Kombinat Przemysłowo-Rolny Igloopol służył jako miejsce uboju zwierząt. W 1994 roku tereny i budynki zakładów mięsnych nabyło niezwykle dynamicznie rozwijające się Przedsiębiorstwo Produkcji Lodów Koral. Wybudowano tam biurowiec oraz halę produkcyjną niezgodnie z pozwoleniem na budowę. Miejsce to do dziś pozostaje niewykorzystane i puste - produkcja lodów nie została tu uruchomiona ${ }^{4}$.

Skala budynku przytłacza i zaburza subtelną i przyjazną skalę miasta. Hala jest około 10-krotnie większa od ratusza miejskiego i około dwukrotnie od przyrynkowych kwartałów zabudowy. Jej sąsiedztwo z ruinami zamku jest rażące. Także inne obiekty i funkcje działające u podnóża miasta i zamku negatywnie wpływają na percepcję i użytkowanie miejsca - budynek przeznaczony do rozbiórki, niszczejący zabytkowy Młyn Jezuicki z 1843 roku i rozległy parking dla tirów.

W przedstawionym projekcie podjęto dwa wątki - w skali całego zespołu miejskiego przedstawiono koncepcję zagospodarowania strefy rekreacyjnej wzdłuż Dunajca i Kamienicy, w skali architektonicznej natomiast obiekt Centrum Promocji Regionu.

\section{STREFA REKREACYJNA NOWEGO SĄCZA}

Właściwe zagospodarowanie strefy nadrzecznej warunkowane jest uporządkowaniem relacji w obrębie całego obszaru śródmiejskiego, stąd zaproponowano szersze spojrzenie na całą strukturę miasta i przedstawiono propozycję jej uładzenia.

Głównym założeniem planistycznym było uporządkowanie komunikacji i innych sektorów miasta. Zachowanie zabytkowego układu urbanistycznego, zachowanie skali i tożsamości 
Starego Miasta, również przez uporządkowanie i ograniczenie zabudowy na przedpolu widokowym, jest rzeczą priorytetową.

Zmiany komunikacyjne, wprowadzone do projektu, to domknięcie istniejących i stworzenie nowych obwodnic miasta dla upłynnienia ruchu oraz odbarczenie ścisłego centrum z ruchu kołowego. Konieczne wydaje się stworzenie nowych połączeń brzegów Dunajca przez tworzenie mostów oraz kładek pieszo-rowerowych. W projekcie zaproponowane zostały 3 nowe połączenia dla ruchu kołowego, 2 kładki oraz zmiana lokalizacji istniejącego mostu im. Józefa Piłsudskiego (przeniesienie na północ od bieżącej lokalizacji, za miejsce ujścia Kamienicy do Dunajca). Istotne było również uporządkowanie ruchu pieszego. Został on wzmocniony w obszarze wokół rynku oraz przy terenach zielonych. Pomiędzy przestrzenie rekreacyjne zostały wprowadzone ciągi pieszo-rowerowe, tak by użytkownicy płynnie przemieszczali się pomiędzy obiektami. Większość ciągów pieszych została wprowadzona prostopadle do dróg dla samochodów w taki sposób, aby stworzyć węzły zależności dla osób różnorodnie się przemieszczających przy jednoczesnym zachowaniu komfortu i miejsca dla obydwu sposobów komunikacji. Aleja Wolności zmieniła swoją funkcję z drogi o ruchu kołowym na deptak oraz drogę rowerową, tworząc ważne uzupełnienie związków funkcjonalnych pomiędzy Starym Miastem a dworcem autobusowym i kolejowym. Dzięki temu zabiegowi osoby wysiadające na dworcu będą mogły bez problemu sprecyzować swój cel podróży, gdyż powstanie kompleksowe i czytelne połączenie pomiędzy węzłem komunikacyjnym przy dworcu a Starym Miastem. Będzie można pokonać ten dystans w przyjaznym zielonym otoczeniu pieszo bądź skorzystać z komunikacji miejskiej lub indywidualnego transportu. W zmianach komunikacyjnych nacisk położony został na ożywienie i promocję ruchu pieszego, rowerowego oraz transportu publicznego. Dla odbarczenia ścisłego centrum od ruchu samochodowego, dla usprawnienia komunikacji w tym terenie oraz dla zachęcenia do skorzystania z innych środków przemieszczania się zostały zaproponowane 3 miejsca na park\&ride, zlokalizowane blisko centrum. Pierwsze przy wjeździe do miasta od północnej strony, pod proponowanym w projekcie Centrum Informacyjno-Usługowym z hotelem. Drugie przy ul. Jana Matejki w sąsiedztwie popularnego w mieście targu warzywnego, na wschód od centrum, oraz trzecie miejsce po zachodniej stronie Starego Miasta przy ul. Szwedzkiej. Tak zlokalizowane przestrzenie parkingowe zapewnią kompleksową obsługę użytkowników z każdej strony centrum.

Istotnym aspektem było również uzupełnienie, usystematyzowanie i zakomponowanie zieleni miejskiej, jako przestrzeni wzajemnie powiązanej, umożliwiającej poruszanie się pomiędzy poszczególnymi miejscami bez konieczności utraty zielonego kontekstu. Projekt zapewnia uzupełnienie zieleni urządzonej wzdłuż obu rzek i wprowadzenie tam ścieżek pieszych oraz rowerowych, a także stworzenie miejsc odpoczynku i aktywnego spędzania czasu. Na wysokości parku Strzeleckiego oraz wzdłuż ulicy Wałowej powstały również piesze połączenia pomiędzy strefami zielonymi przy Dunajcu i Kamienicy, zapewniające komunikację pomiędzy obiektami sportowymi. Te połączenia zapewniają także relację i możliwość 
spotkania się dróg osób wybierających aktywny wypoczynek na łonie natury z tymi, które zdecydowały się zwiedzać miasto. Łatwy dostęp do atrakcyjnych i różnorodnych pod względem funkcji miejsc zapewni zwiększenie aktywności w obszarze miasta. Pięknym, jednak oddalonym od centrum, miejscem jest Sądecki Park Etnograficzny, składający się z Miasteczka Galicyjskiego oraz Skansenu Regionalnego o powierzchni około 20 ha. Połączenie Skansenu z pozostałymi kulturalnymi i rekreacyjnymi strefami spowodowałoby znaczne uatrakcyjnienie oferty turystycznej.

Obszarem wymagającym zmiany funkcji atrakcyjnych lokalizacji jest bez wątpienia strefa Starego Miasta. Zabudowa kwartałowa wokół rynku, poza funkcją mieszkaniową, zawiera usługi w parterach, jednak ich dobór nie generuje ruchu mieszkańców i turystów w tym zakresie. Są to bowiem w przeważającej części banki, punkty sieci komórkowych, niekiedy sklepy odzieżowe. Podobnie sprawa wygląda wzdłuż najpopularniejszego deptaku przy ulicy Jagiellońskiej - restauracji czy kawiarni trzeba tam długo szukać w gąszczu oddziałów bankowych. Wprowadzenie w rejonie ścisłego centrum miejsc wypoczynkowych oraz atrakcyjnych obiektów gastronomicznych i kulturowych, działających o różnych porach, ożywiłoby przestrzeń Starego Miasta, które obecnie pustoszeje z wybiciem godziny 18 . Wyeksponowanie obiektów zabytkowych, których nie brakuje w historycznym mieście, i zapewnienie kompleksowego, spójnego programu kulturalno-turystycznego zwiększyłoby atrakcyjność miejsca. Projekt przewiduje stworzenie trasy dla zwiedzających oraz dla spacerujących mieszkańców, dającej możliwość odwiedzenia miejsc atrakcyjnych w sposób ciągły i zaplanowany. Przeplatanie się miejsc zabytkowych ze strefami zielonymi stworzyłoby przyjazną i chętnie odwiedzaną przestrzeń.

Istnieją również miejsca, których poprawa jakości wzmocniłaby i rozwinęła ich potencjał, jak na przykład lokalny targ warzywny, zwany Maślanym Rynkiem. Podniesienie atrakcyjności i poprawa jakości tego miejsca spowodowałyby większe zainteresowanie lokalnymi przysmakami i zdrowymi produktami, które można nabyć na rynku.

Teren zbiegu rzek będący kluczowym miejscem dla przedstawionych koncepcji w obu skalach musi być w klarowny sposób powiązany ze Starym Miastem. Stąd korekty wymaga tu infrastruktura drogowa, która przecinając bezmyślnie teren, dzieli go i ogranicza wykorzystanie. Proponowane zmiany obejmują translokację mostu im. Józefa Piłsudskiego na obszar poza ujściem rzeki Kamienicy, ograniczenie ruchu kołowego, prowadzącego do centrum oraz wprowadzenie strefy park\&ride z możliwością zmiany środka transportu indywidualnego na komunikację miejską bądź rowerową.

W miejscu przedwojennego mostu nad Dunajcem zaproponowana została kładka pieszo-rowerowa. Wprowadzone zostały również nadziemne kładki rowerowe i piesze we wschodniej części projektu łączące strefę nadrzeczną i zapewniające dostęp do Starego Miasta. Tereny nadrzeczne zostały uzupełnione o atrakcyjne trasy biegowe, rowerowe oraz piesze wyposażone w miejsca wypoczynkowe, polowe siłownie, miejsca zabaw dla dzieci oraz nadrzeczne miejsca do opalania i łowienia ryb. 
Odbarczenie ścisłego centrum zaowocowało wygospodarowaniem przestrzeni wypoczynkowej, rekreacyjnej oraz terenów sportowych. Istniejąca zieleń została uporządkowana i uzupełniona o nową, która jest wprowadzona fragmentarycznie, aby nie przysłonić widoku na Tatry oraz dla pozostawienia czytelnego przedpola widokowego Starego Miasta.

Tereny rekreacyjne zyskały nowe obiekty kubaturowe. Jednym z nich jest hotel połączony z Centrum Informacyjno-Usługowym wraz z punktem przesiadkowym park\&ride wkomponowany we wzgórze, na którym zlokalizowane jest Stare Miasto. Budynek o funkcji zamieszkania zbiorowego połączony z centrum informującym o atrakcjach dostępnych w mieście i regionie oraz miejscem przesiadkowym umożliwiającym zaplanowanie i wybór środka transportu stanowi ważny element w promowaniu regionu i zwiększaniu atrakcyjności i dostępności miasta dla turystów.

Innym obiektem znajdującym się na projektowanym terenie jest zaadaptowany na Centrum Wystawiennicze istniejący Młyn Jezuicki będący obiektem zabytkowym z 1843 roku. Rewitalizacja terenów wokół starego młyna znacznie podniosłaby atrakcyjność tej przestrzeni.

Głównym obiektem zaproponowanym w tak określonej strukturze jest Centrum Promocji Regionu pomyślany jako dominanta programowa o różnorodnych funkcjach edukacyjnych i rekreacyjno-sportowych. Obiekt stanowi subtelne uzupełnienie atrakcji niekubaturowych. „Jeśli budynek nie będzie ukierunkowany w stronę otoczenia zewnętrznego równie starannie i pozytywnie, jak w stronę wnętrza, przestrzeń wokół niego będzie bezbarwna i bezużyteczna"”.

\section{CENTRUM PROMOCJI REGIONU}

Centrum zlokalizowano u zbiegu rzek w ważnym kompozycyjnie punkcie tak dla strefy rekreacyjnej parków rzecznych i ekspozycji Starego Miasta, jak i dla możliwości widokowych szerszego krajobrazu doliny Dunajca i Kamienicy.

Głównym celem projektowym było stworzenie wielofunkcyjnej przestrzeni, pozwalającej przez zabawę i odpoczynek zapoznać się z historią miasta i regionu, skosztować lokalnej żywności oraz korzystać z walorów widokowych, charakterystycznych dla lokalizacji. Budynek ma być wypoczynkowym azylem, z którego korzystaliby zarówno mieszkańcy, jak i turyści w każdym wieku.

Projektowany obiekt obejmuje $5888 \mathrm{~m}^{2}$ powierzchni użytkowej, przy $3003 \mathrm{~m}^{2}$ powierzchni zabudowy i $15125 \mathrm{~m}^{3}$ kubatury. Jego wysokość nie przekracza 12,3 m. Jest budynkiem o przeznaczeniu usługowo-rekreacyjnym, posiada zespół sal konferencyjnych, strefę przeznaczoną dla dzieci, skate park, restaurację i taras widokowy.

Forma obiektu łączy cechy prostej, zgeometryzowanej konstrukcji z zaletami architektury ukrytej w terenie i topograficznie podporządkowanej otwartemu krajobrazowi parku. Taka definicja architektury budynku daje wiele korzyści funkcjonalnych i przestrzennych, pozwalając na zbudowanie programu obsługującego strefę rekreacyjną bez narzucania jej 
formy w ważnym punkcie kompozycyjnym całości, a jednocześnie pozwala stworzyć jego kulminację.

Komunikacyjne relacje obiektu dotyczą zarówno wspomnianej już strefy parkowej (traktami pieszymi lub pieszo-rowerowymi od strony ruin zamku i Starego Miasta, Młyna Jezuickiego oraz parku Strzeleckiego), jak i powiązań prowadzonych wzdłuż ciągów kołowych (ul. Tarnowskiej i ul. P. Skargi).

Główne wejścia do obiektu usytuowano od strony północnej i południowej. Tam też znajdują się wjazdy do podziemnego skate parku służące także rowerzystom.

Budynek reinterpretuje swą formą skalę zabudowy kwartałowej wokół rynku. W najwyższym punkcie przy okapie ma wysokość $12,3 \mathrm{~m}$ (względem poziomu 0,00 znajdującego się na parterze budynku), natomiast w najniższym równa się z terenem znajdującym się na poziomie $+1,85 \mathrm{~m}$. Jest obiektem posiadającym jedną kondygnację podziemną oraz jedną nadziemną z częściowo wydzielonymi antresolami. Konstrukcja budynku składa się z okrągłych słupów stalowych rozmieszczonych na siatce o module 18x18 m. Część podziemna posiada konstrukcję żelbetową. Dach w kształcie paraboloidy hiperbolicznej jest prętową strukturą przestrzenną stalową w formie dwukrzywiznowej prostokreślnej, skonstruowaną z kratownicy łączonej w węzłach za pomocą odlewów gwintowanych, połączonej ze słupami za pomocą łożysk elastomerowych ${ }^{6}$.

Strefy w budynku zostały wydzielone na podstawie docelowych grup odbiorców. W kondygnacji podziemnej znajduje się skate park z torem rowerowym pump track doświetlony bezpośrednio światłem dziennym oraz połączony z parterem schodami, windą, a także wizualnie dwoma świetlikami umożliwiającymi podziwianie akrobacji z wyższej kondygnacji budynku.

Wnętrze parteru to przestrzeń ekspozycyjna, którą zaaranżowano na wzór dziedzińców zabudowy w Starym Mieście. Znajdziemy tam także restaurację (z zapleczem kuchennym i socjalnym) promującą lokalną żywność i regionalne potrawy, przestrzeń zabaw dla dzieci, wypoczynkowy labirynt, a także wydzieloną niewielką salę projekcyjną oraz sale warsztatowe i funkcje obsługujące (szatnia, portiernia, toalety).

Wydzielone antresole to przeszklone czytelnie z pięknym widokiem na miasto. Prowadzą do nich podwieszane schody oraz winda.

Całość obiektu podporządkowana jest funkcji poznawczej i edukacyjnej, mając na celu pogłębienie wiedzy na temat miasta. Dzięki zastosowaniu systemu mobilnych totemów, będących elementami gry interaktywnej, osoby, przemierzając budynek, będą mogły zdobywać wiedzę o regionie, prowadzić zabawę całymi rodzinami oraz konkurować z innymi użytkownikami.

Dach, będący tarasem użytkowym, pozwala w pełni wykorzystać elementy budynku, stwarzając wyjątkowe miejsce z widokiem na Tatry i ruiny zamku oraz kreując pewnego rodzaju widownię dla wydarzeń, które mogą się odbywać na placu przed obiektem.

Krawędzie budynku stanowią istotny element i nie należy traktować ich jedynie jako styku strefy zewnętrznej i wewnętrznej. Dla stworzenia relacji pomiędzy tymi przestrzeniami 
elewacje Centrum Promocji Regionu stanowią szklane ściany osłonowe. Ściany pełne występują w miejscach funkcji technicznych i zaplecza obiektu.

\section{PODSUMOWANIE}

Główne cele zrealizowane w projekcie to:

- uporządkowanie strefy wokół zespołu przestrzennego historycznego centrum Nowego Sącza,

- uporządkowanie przyrodniczej strefy nadrzecznej Dunajca i Kamienicy,

- uporządkowanie powiązań pieszych, rowerowych i kołowych,

- nowa definicja funkcji,

- scalenie formalne i kompozycyjne zespołu przestrzennego historycznego centrum Nowego Sącza,

- zdefiniowanie Centrum Promocji Regionu - nowego punktu programowo-kubaturowego o walorach punktu widokowego w formule architektury topograficznej. 

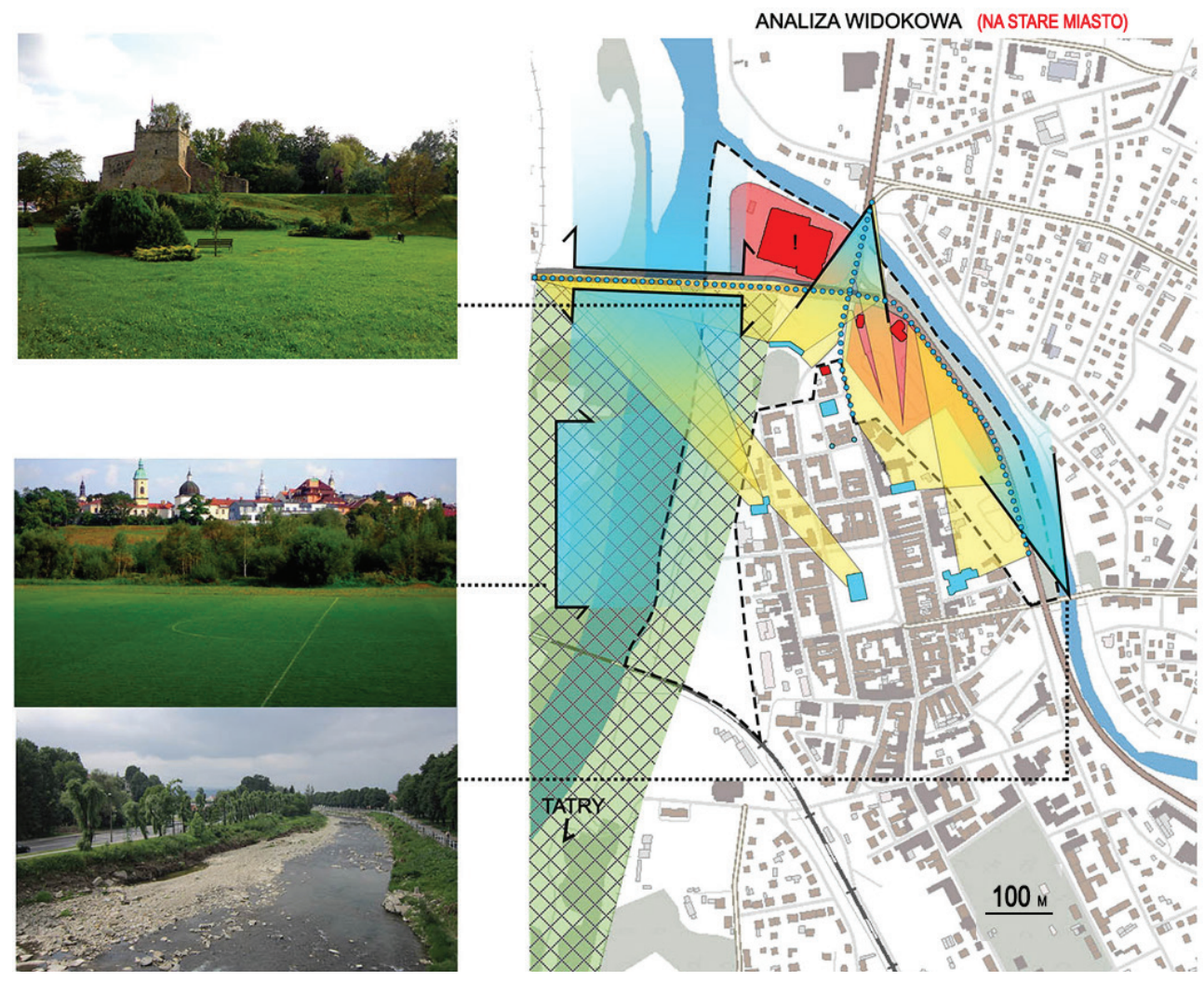

LEGENDA:

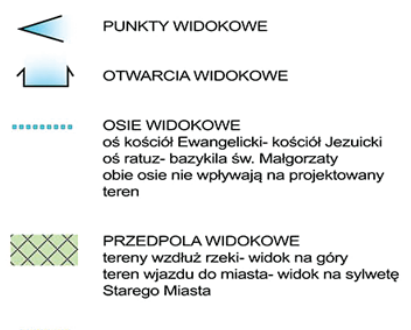
DOMINANTY POZYTYWNE ruiny Zamku Krolewskiego - Bazylika św. Małgorzaty - Kosciół Jezuicki
DOMINANTY NEGATYWNE - hala produkcyjna i biurowa

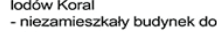 - niezamieszkały budynek do
rozbiórki rozbiorki
- budynek Młynu Jezuickiego - teren parkingu ciężarowego AKCENTY

STREFY WIDOKOWE

przestrzenie z których obserwojemy konk-

retne obiekty starego miasta

II. 1. Nowy Sącz - uwarunkowania przestrzenne I. Analiza widoków - z zewnątrz na Stare Miasto (autorka: Iwona Niemiec) III. 1. Nowy Sącz - spatial determinants I. Analysis of views - from the outside to the Old City 


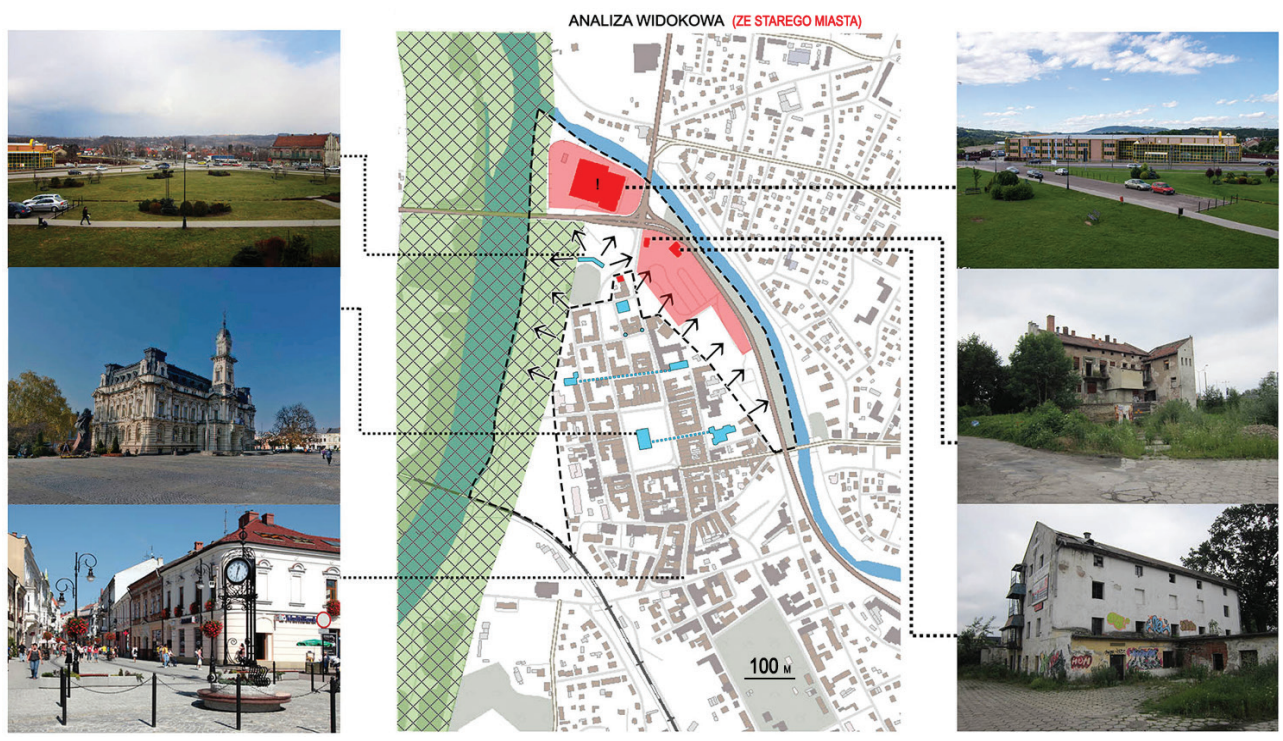

LEGENDA:

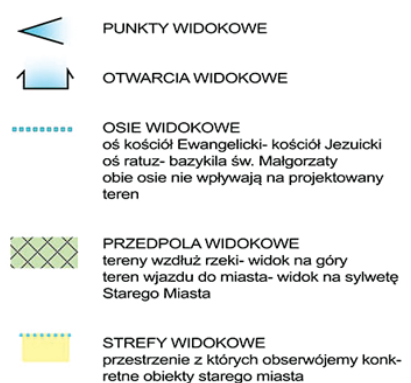

DOMINANTY POZYTYWNE - ruiny Zamku Królewskiego
- Ratusz

- Bazylika św. Małgorzaty

- Kościół Ewangelicki

-Kosciót Jezuick

DOMINANTY NEGATYWNE - hala produkcyjna i biurowa lodów Kora

- niezamieszkały budynek do

- budynek Młynu Jezuickiego

- teren parkingu ciężarowego

AKCENTY

przestrzenie z których obserwójemy konk-

II. 2. Nowy Sącz - uwarunkowania przestrzenne II. Analiza widoków - relacje wewnętrzne oraz na zewnątrz z krawędzi Starego Miasta (autorka: Iwona Niemiec; źródła fotografii: a, e, f - Iwona Niemiec; b - http://nowysacz.wkraj. pl/\#/76768/272,-9; c - www.nowysacz.pl, d - http://fotopolska.eu)

III. 2. Nowy Sącz - spatial determinants II. Analysis of views - internal relations and views outside from the edge of the Old City 

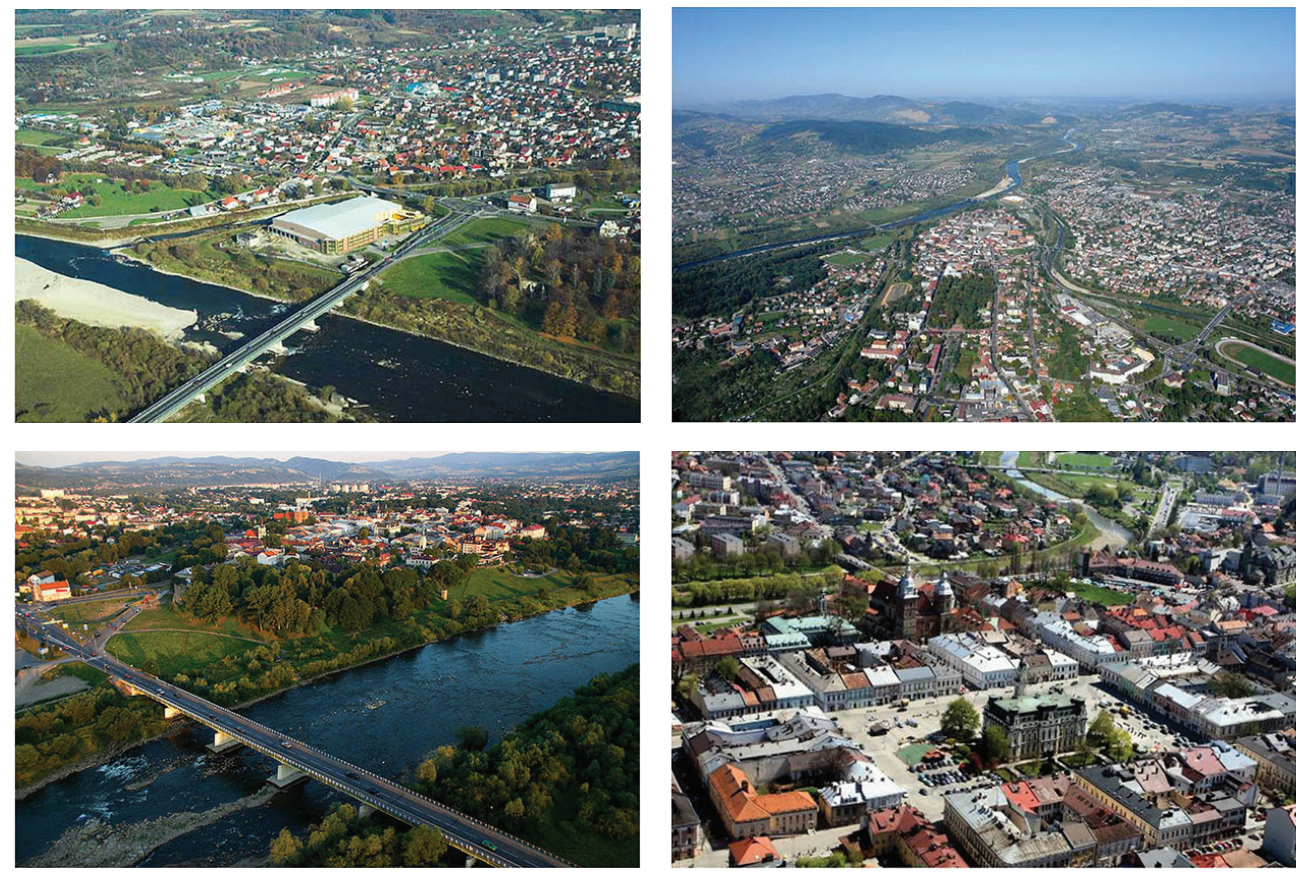

II. 3. Nowy Sącz - uwarunkowania przestrzenne III. Istniejąca struktura: a - ujście Kamienicy do Dunajca, b - Nowy Sącz, widok z lotu ptaka, c - most im. J. Piłsudskiego i Stare Miasto, widok z lotu ptaka, d - Rynek Starego Miasta, widok z lotu ptaka (źródła fotografii: a - www. malgorzatakossakowska.pl; b, c - www.skyscrapercity.com, d - www.nowysacz.naszemiasto.pl)

III. 3. Nowy Sącz - spatial determinants III. Existing structure: a - confluence of Dunajec and Kamienica rivers, b-bird view of the City of Nowy Sącz, c - bird view of J. Piłsudski Bridge and the Old City, $d-$ bird view of Old Marketplace 

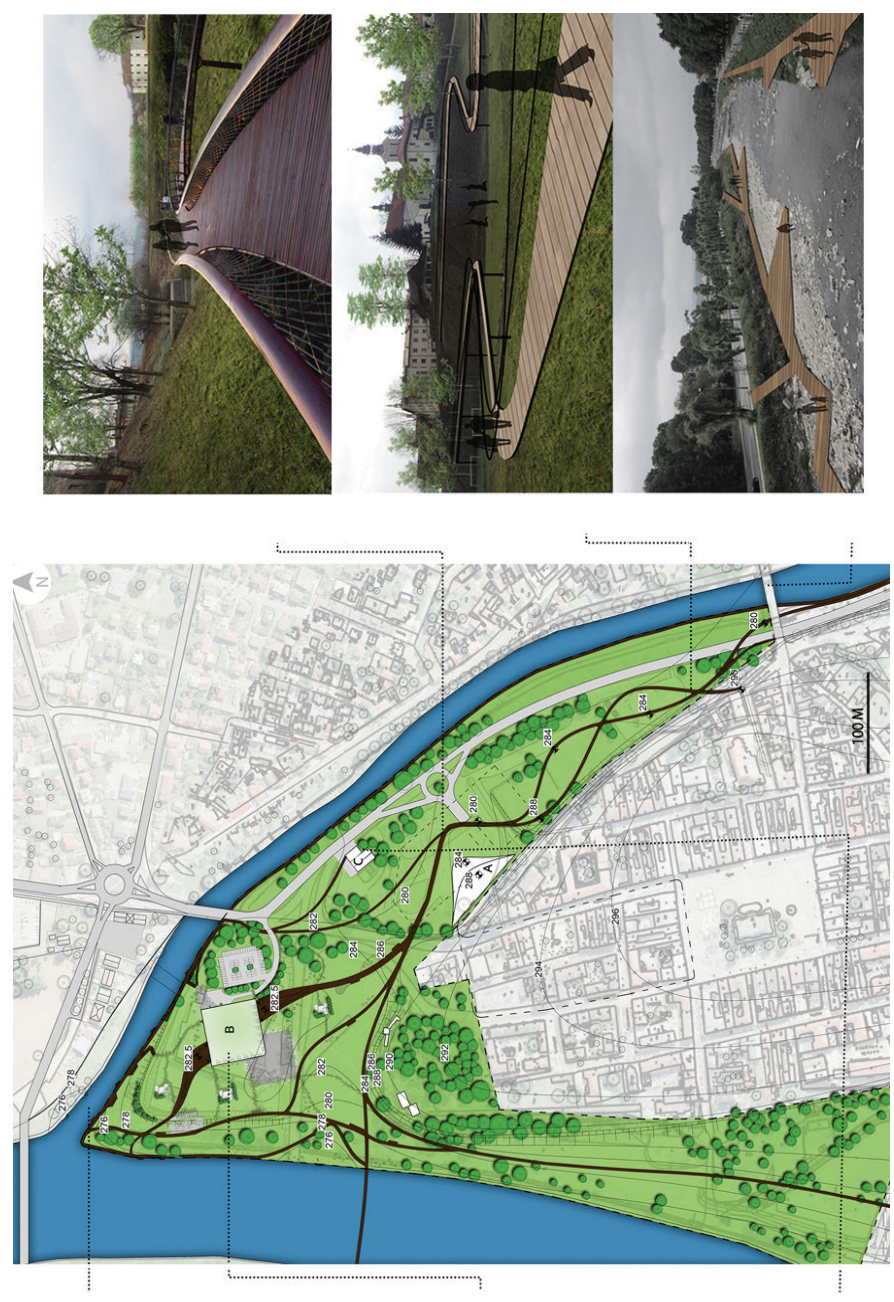

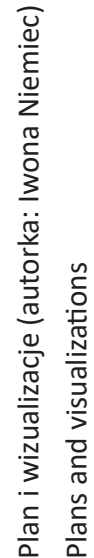
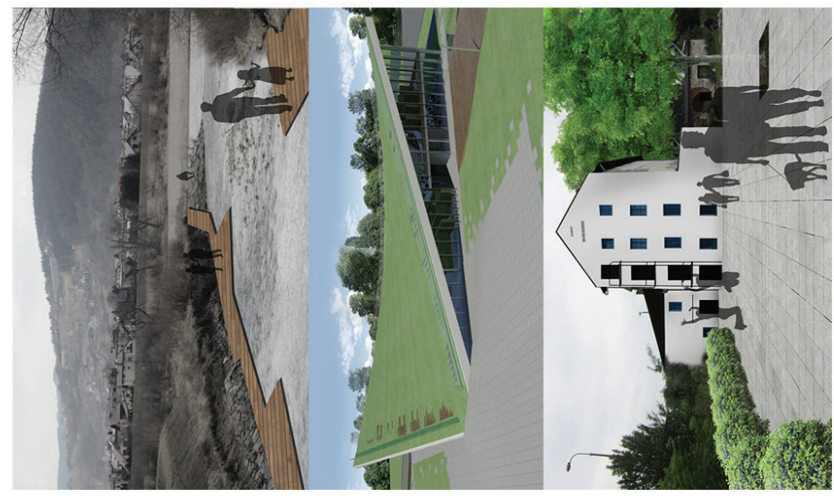

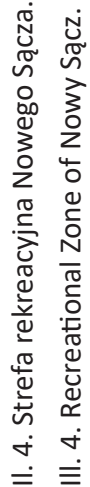




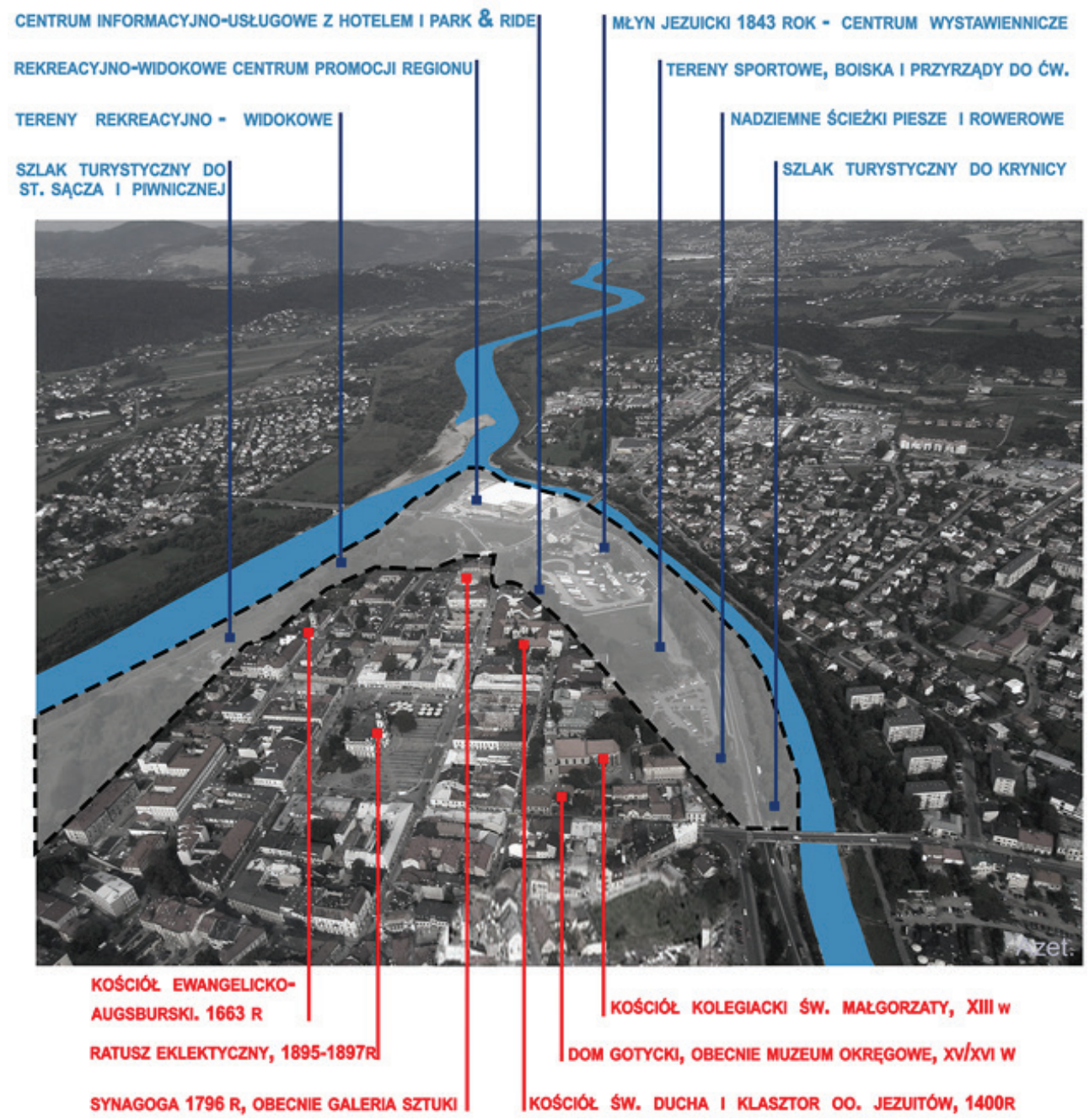

II. 5. Nowy Sącz. Ogólne zasady rozmieszczenia funkcji strefy rekreacyjnej w relacji do obiektów zabytkowych Starego Miasta (autorka: Iwona Niemiec)

III. 5. Nowy Sącz. General location of functions in Recreational Zone in relations to historical buildings in the Old City 


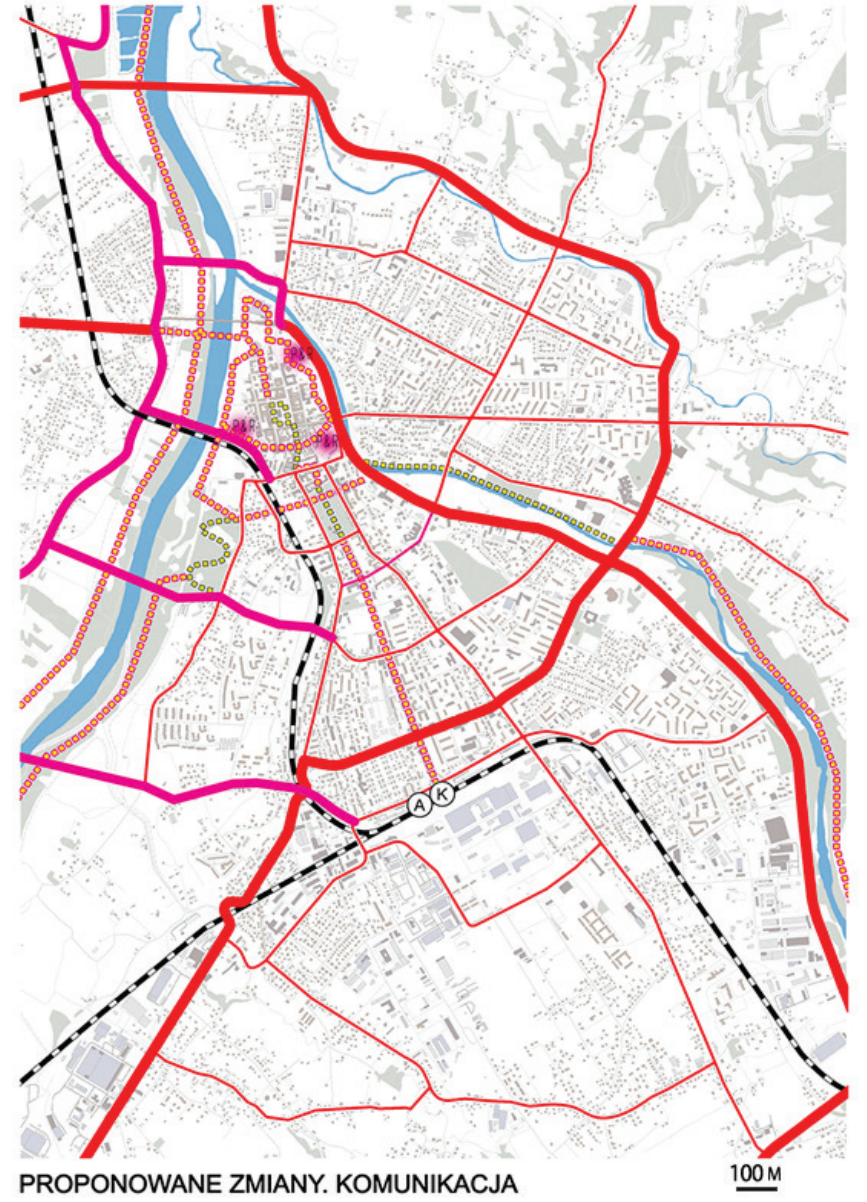

\section{LEGENDA:}

ISTNIEJACE GtÓWNE CLĄG KOMUNIKACYJNE

ISTNIEJACE DROGI O SREDNIM NATEZZENIU RUCHU

ISTNIEJĄCA SIEC KOLEJOWA

(K) ISTNIEJACYYDWORZEC KOLEJOWY

ISTNIEJACEE CIAGGI PIESZE

PROJEKTOWANE UZUPEENIENIA GKÓWNYCH CIAGOWKOMUNIKACYJNYCH

domknięcla istniejących drog o dużym natężeniu ruchem samochodowym lub zmianafunkcji
istniejacych ulic. Stworzenie sieci obwodnic istniejących ulic. Stworzenie sieci obwodnic
celem odbarczenia ulic w centrum miasta. Ulatcelem odbarczenia ulic w centrum miasta. Ulat-
wienie komunikacji w obręcie okolicznych miejscowości. Uzupelnienie infrastruktury o mosty laczace brzegi Dunajca w rejonie calego miasta.

PROJEKTOWANE DROGI O SREDNIM NATEZZZENIU RUCHU

drobne zmiany w obrecie sieci dróg wewnątrz miasta w celu usprawnienia komunikacij

(A) DWORCEAUTOBUSOWE

istniejacy dworzec autobusowy MPK wraz z projektowanym przeniesionym dworcem PKS. Stworzenie kompleksowego dworca w jednym miejscu z dostępem do różnych form transportu oraz $z$ ulatwionym intuicyjnym dostępem do Starego Miasta

PROJEKTOWANE STREFY PARK\&RIDE

3 strefy przesiadkowe promujace komunikacje miejskim transportem publicznym oraz rowerowym i pieszym. Ich lokalizacja zapewnia latwy dostẹp do ścislego centrum dla użytkownków z każdej części miasta.

PROJEKTOWANE CIĄGI PIESZE I ROWEROWE

uzupelnienie infrastruktury ○ rozbudowana strukturę dla pieszych i rowerzystów. Zmiana wykorzystania Alei Wolności oraz ulicy Walowej z ulic o ruchu kolowym na ciagi piesze i rowerowe. Stworzenie kladki oraz rozbudowanej siatki ciagów pieszo-rowerowych w obrębie stref rekreacyjnych

II. 6. Nowy Sącz. Proponowane zmiany - komunikacja (autorka: Iwona Niemiec)

III. 6. Nowy Sącz. Proposed changes - transportation system 


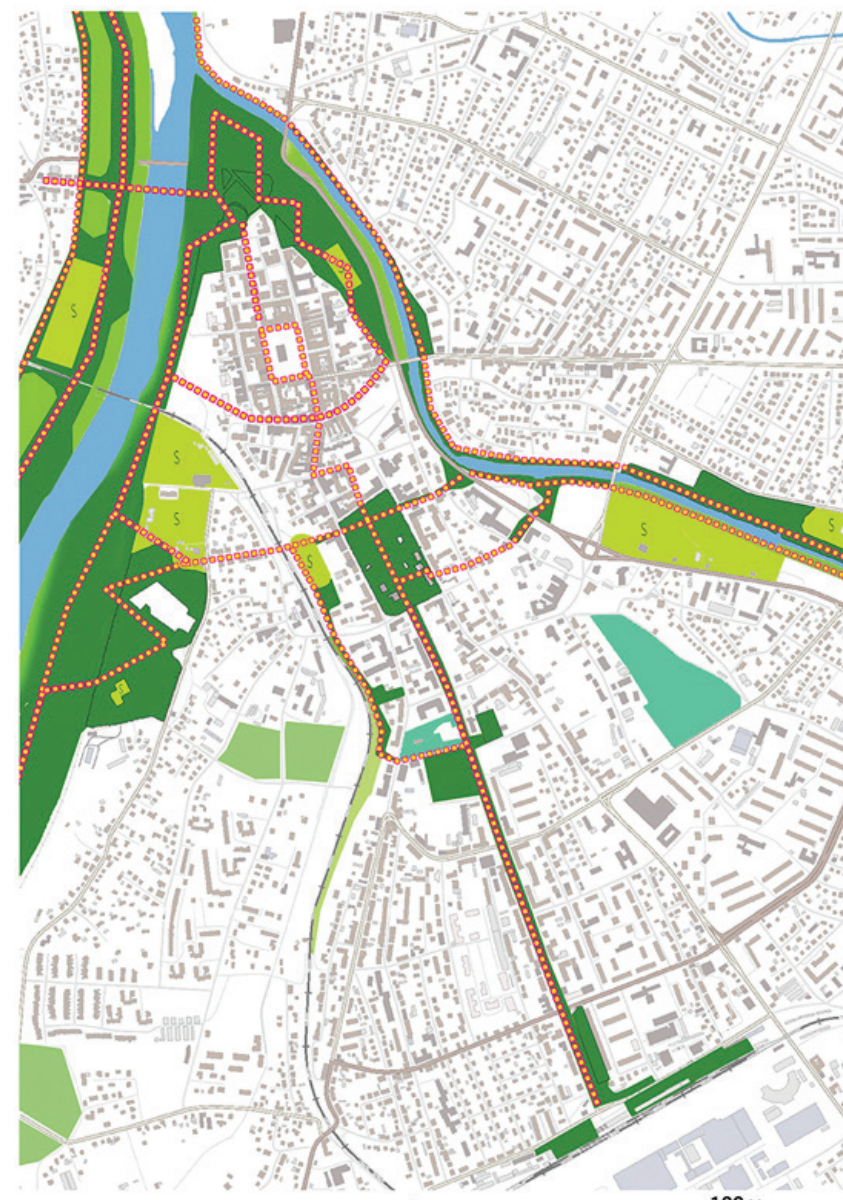

PROPONOWANE ZMIANY: ZIELEŃ, PIESI, ROWERY

\section{LEGENDA:}

ZIELEŃ URZADZZONA. ZME,KSZENIE OBSZARU

Powiekszzenie terenów parków i urzadzonych przestrzeni zielonych. Zwiekszenie ich ilości o zagospodarowanie terenów znajdujących sie wwidlach rzekDunajeciKamienica po obu stro nach rzek. Poprawienie jakości istniejących parków. Stworzenie spójnej powiązanej sieci zielonych zalozen parkowych pozwalajacej nie tylkona urzystkowanie aletakże na przyjazne przemieszczanie się dla pieszych

i rowerzystów.

ZIELEŃ KEGGOWA

częsciowe wykorzystanie terenów nadrzec znych wzoduz Dunajca i Kamienicy na przestrzenie rekreacyjne i urządzone strefy.

$S$ TERENY SPORTOWE

uzupenienie istniejacych terenów sportowych o siatkę wzajemnej komunikacji

ISTNIEJACE TERENY CMENTARZY wokól cmentarzy występuje $50 \mathrm{~m}$ pas ochronny ISTNIEJACE TERENY OGRÓDKOOW DZIALKOWYCH

\section{CIAAGI PIESZE}

uzupetnienie struktury miasta o drogi rowerowe $\mathrm{i}$ ciagi piesze $\mathrm{z}$ naciskiem na ich wystepowanie na terenach rekreacyinych,wzdibz rzek, w centrum miasta oraz pomiędzy ważnymi ośrodkami w celu ulatwiepomiędzy ważnymi ośrodkami w celu ulatwienia i zwiększenia komfortu użytkowników oraz promowaniakorzy komunikacji

II. 7. Nowy Sącz. Proponowane zmiany - zieleń, ścieżki piesze i rowerowe (autorka: Iwona Niemiec) III. 7. Nowy Sącz. Proposed changes - greenary, pedestrian and bicycle paths 


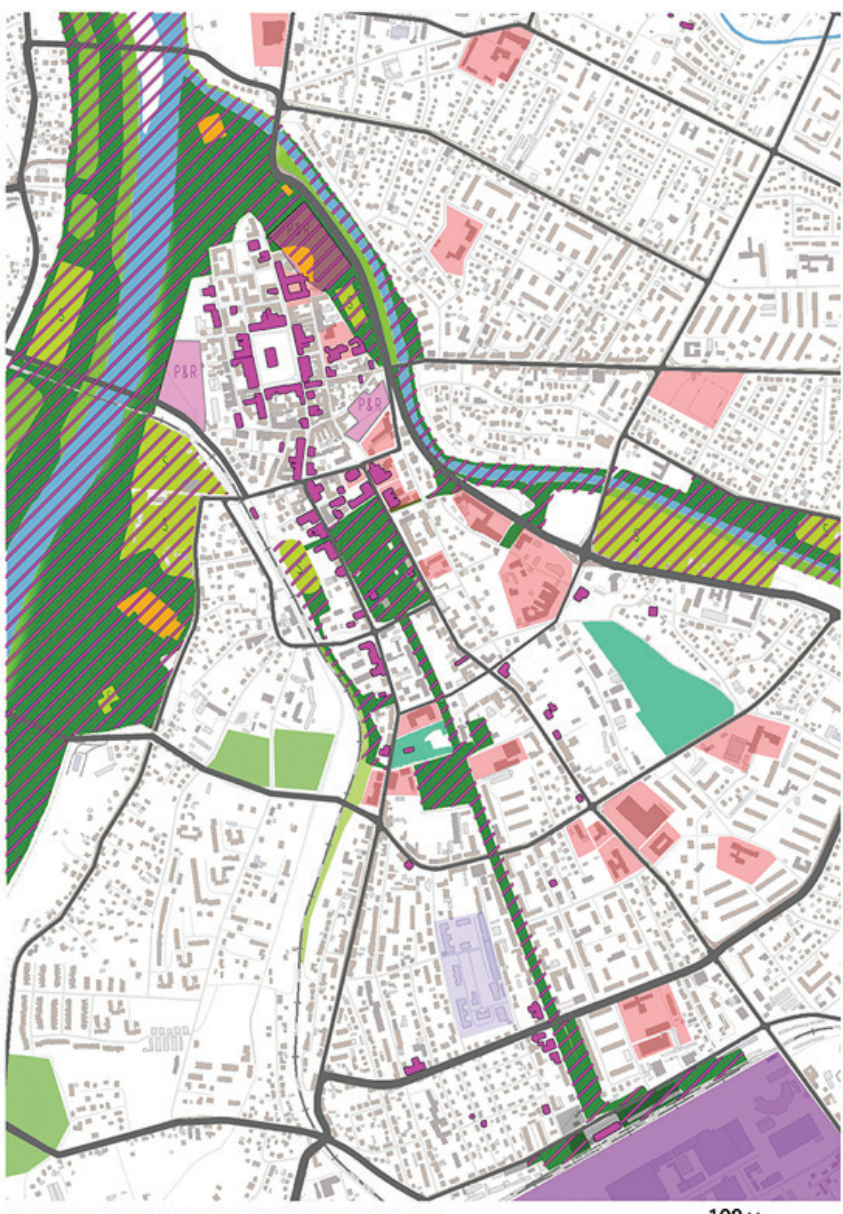

PROPONOWANE ZMIANY. FUNKCJE

\section{LEGENDA:}

OBIEKTY ZABYTKOWE

Wykorzystanie zasobów kulturowych i lokalizacyjnych dla przyciagniecia turystów oraz wzmorzenia nuchu mieszkańców w obrębie Starego Miasta. Stworzenie klarownego systemu zwiedzania dzięki podkreśleniu walorów obiektów zabytkowych.

TERENY REKREACYJNE, SPORTOWE Nacisk na rozwój zaplecza rekreacyjnego wynikajacego z potrzeb spolecznych i lokalizacy. jnych miasta. Wykorzystanie rzek jako miejsca atrakcyinego dla mieszkańców i turystów.

Stworzenie bazy startowej dla turystów chca. cych zwiedzić miasto bądź udać się do poblis. kich ośrodków rekreacyjnych zielonymi ciagami pieszymi i rowerowymi

PROJEKTOWANE STREFY PARK\&RIDE 3 strefy przesiadkowe promujące komunikacje miejskim transportem publicznym oraz rowerowym i pieszym. Ich lokalizacja zapewnia tatwy dostep do ścistego centrum dla uzytkownikớw z każdej części miasta.

OBIEKTY W STREFIE REKREACYJNEJ obiekty kubaturowe występujace bąźz projektowane w strefie rekreacyjnej uzupetniajace przestrzenie parkowe, strefy widokowe, piesze i rowerowe szlaki turystyczne, otwarte tereny sportowe, miejsca zabaw i wypoczynku

II. 8. Nowy Sącz. Proponowane zmiany - funkcja (autorka: Iwona Niemiec)

III. 8. Nowy Sącz. Proposed changes - functions 


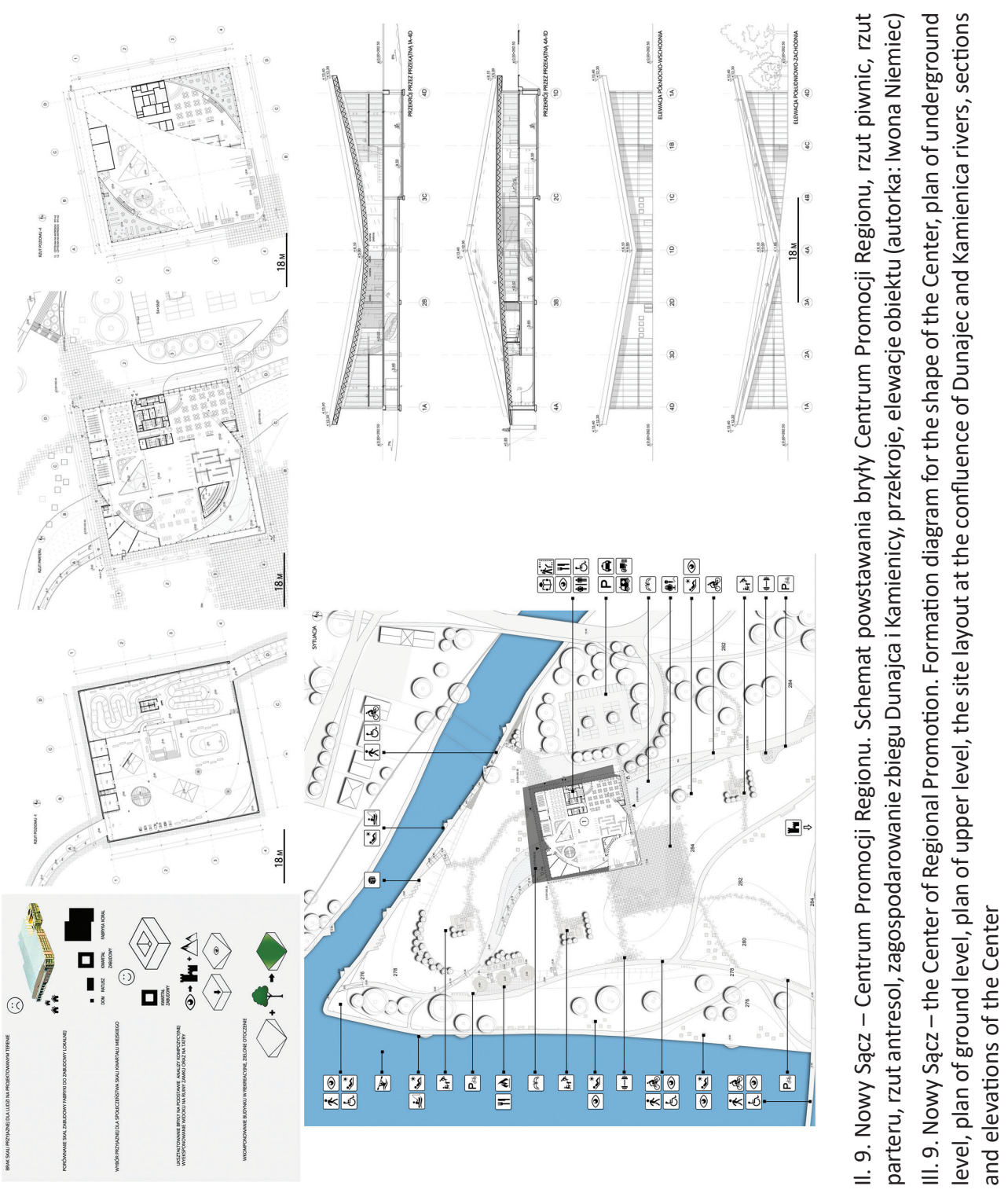




\section{PRZYPISY}

1 K. Wejchert, Elementy kompozycji urbanistycznej, Arkady, Warszawa 1974, s. 22.

2 Por. Metamorph, 9. International Architecture Exhibition, Trajectories, Fondazione La Biennale di Venezia, Marsilio Editori, Venezia 2004; T. Głowacki, Architektura sztucznej topografii - kształtowanie równowagi w krajobrazie kulturowym i naturalnym, „Prace Naukowe Wydziału Architektury Politechniki Wrocławskiej. Architektura Mieszkaniowa", 2011, Vol. 9, nr 7, s. 165-170; E. Węcławowicz-Gyurkovich, Nowe miasto pod ziemia/New Underground City, „Czasopismo Techniczne” 1-A/2007, s. 196-202.

3 www.nowysacz.pl (dostęp: 4.05.2017).

4 www.twojsacz.pl (dostęp: 4.05.2017).

5 Ch. Alexander, S. Ishikawa, M. Silverstein, I. Fiksdahl-King, A. Shlomo, Język wzorców. Miasta - Budynki - Konstrukcja, Wyd. GWP, Gdańsk 2008, s. 763.

6 W. Borusiewicz, Konstrukcje budowlane dla architektów, Arkady, Warszawa 1978, s. 204, 287-290, 341.

\section{BIBLIOGRAFIA}

\section{Wydawnictwa książkowe}

Alexander Ch., Ishikawa S., Silverstein M., Fiksdahl-King I., Shlomo A., Język wzorców. Miasta - Budynki-Konstrukcja, Wyd. GWP, Gdańsk 2008.

Borusiewicz W., Konstrukcje budowlane dla architektów, Arkady, Warszawa 1978.

Metamorph, 9. International Architecture Exhibition, Trajectories, Fondazione La Biennale di Venezia, Marsilio Editori, Venezia 2004.

Ruby I., Ruby A., Groundscapes, the rediscovery of the ground in contemporary architecture, Ed. Gustavo Gili, Barcelona 2006.

Wejchert K., Elementy kompozycji urbanistycznej, Arkady, Warszawa 1974.

\section{Czasopisma}

Głowacki T., Architektura sztucznej topografii - kształtowanie równowagi w krajobrazie kulturowym i naturalnym, „Prace Naukowe Wydziału Architektury Politechniki Wrocławskiej. Architektura Mieszkaniowa”, 2011, Vol. 9, nr 7, s. 165-170.

Węcławowicz-Gyurkovich E., Nowe miasto pod ziemiq/New Underground City, „Czasopismo Techniczne" 1-A/2007, s. 196-202. 


\section{Strony internetowe}

www.nowysacz.pl (dostęp: 4.05.2017).

www.twojsacz.pl (dostęp: 4.05.2017).

http://nowysacz.wkraj.pl/\#/76768/272,-9 (dostęp: 10.06.2017).

http://fotopolska.eu (dostęp: 10.06.2017).

www.malgorzatakossakowska.pl (dostęp: 10.06.2017).

www.skyscrapercity.com (dostęp: 10.06.2017).

www.nowysacz.naszemiasto.pl (dostęp: 10.06.2017). 